\title{
FINANSOWE ASPEKTY WSPÓŁPRACY JEDNOSTEK SAMORZĄDU TERYTORIALNEGO Z ORGANIZACJAMI POZARZĄDOWYMI PRZY REALIZACJI ZADAŃ PUBLICZNYCH
}

\author{
THE FINANCIAL ASPECTS OF COOPERATION \\ BETWEEN LOCAL SELF-GOVERNMENT UNITS \\ AND NGOS IN PERFORMING PUBLIC SERVICES
}

\begin{abstract}
Streszczenie
Jednostki samorządu terytorialnego zobowiązane są do realizacji różnego rodzaju zadań wynikających z przepisów licznych ustaw. Zadania te wykonywane są w interesie ogólnospołecznym. Część z nich może zostać powierzona podmiotom nie należącym do sektora finansów publicznych - organizacjom pozarządowym. Organizacje pozarządowe, w tym ich szczególna forma, jaką są organizacje pożytku publicznego, niejednokrotnie są w stanie realizować zlecone im zadania publiczne efektywniej i taniej, niż czyniłby to samorząd za pomocą swoich własnych jednostek organizacyjnych. Wspótpraca j.s.t. i organizacji pozarządowych jest wielowymiarowa. Jednym $\mathrm{z}$ istotnych jej aspektów jest kwestia finansowania zadań zleconych NGOs. Aby organizacja pozarządowa mogła realizować zlecone jej zadania publiczne, samorząd musi zapewnić niezbędne środki finansowe. Celem artykułu jest ogólna charakterystyka dotacyjnego mechanizmu finansowania organizacji pozarządowych z budżetów jednostek samorządu terytorialnego.
\end{abstract}

Słowa kluczowe: organizacje pozarządowe; organizacje pożytku publicznego; dotacje celowe; finanse jednostek samorządu terytorialnego w Polsce. 


\begin{abstract}
Local self-government units are obliged to provide numerous public services that are imposed by the provisions of law. These tasks are performed in the interest of the society. Some of them may be transferred to entities known as non-governmental organizations (NGOs). Non-governmental organizations, a part of so-called non-profit sector, are usually able to perform assigned tasks more efficient and cheaper than local self-governments would do itself. Cooperation between local self-governments and non-governmental organizations is multidimensional. One of its most important aspects is the matter of financing NGOs. Non-governmental organization could carry out public tasks only if sufficient financial resources are provided. The aim of the article is to present the general characteristics of the grant funding mechanism for non-governmental organizations involving the local governments budgets.
\end{abstract}

Keywords: non-governmental organizations; public benefit organizations; budget grants; financial system of local self-government in Poland.

\title{
1. Wprowadzenie
}

Po wielu latach starań, 24 kwietnia 2003 r. uchwalona została ustawa o działalności pożytku publicznego i o wolontariacie ${ }^{1}$. Akt ten, wraz z przepisami wykonawczymi, stał się podstawowym źródłem prawa określającego zasady funkcjonowania organizacji pozarządowych w Polsce.

W świetle definicji legalnej zawartej w art. 3 ust. 1 u.d.p.p.w., działalnością pożytku publicznego jest działalność społecznie użyteczna, prowadzona przez organizacje pozarządowe w sferze zadań publicznych. Podmioty zaliczane do organizacji pozarządowych wymienione zostały natomiast w art. 3 ust. 2 ustawy. Są nimi osoby prawne lub jednostki organizacyjne nieposiadające osobowości prawnej, którym odrębna ustawa przyznaje zdolność prawną, w tym fundacje i stowarzyszenia, które spełniają kumulatywnie dwie przesłanki: nie należą do sektora finansów publicznych (w rozumieniu przepisów prawa finansowego ${ }^{2}$ ) ani nie działają w celu osiągnięcia zysku.

Tekst jedn. Dz.U. z 2016 r., poz. 817 ze zm., dalej: ustawa o d.p.p.w. / u.d.p.p.w.

2 Ustawa z dnia 27 sierpnia 2009 r. o finansach publicznych (tekst jedn. Dz.U. z 2016 r., poz. 1870 ze zm.), dalej: u.f.p. Zgodnie z art. 9 u.f.p. sektor finansów publicznych tworzą: organy władzy publicznej, w tym organy administracji rządowej, organy kontroli państwowej i ochrony prawa oraz sądy i trybunały; jednostki samorządu terytorialnego oraz ich związki; związki metropolitalne; jednostki budżetowe; samorządowe zakłady budżetowe; agencje wykonawcze; instytucje gospodarki budżetowej; państwowe fundusze celowe; 
Katalog zadań publicznych, które mogą być wykonywane przez organizacje pozarządowe $\mathrm{w}$ ramach prowadzonej działalności pożytku publicznego, ustawodawca określił w art. 4 u.d.p.p.w. Rozbudowane wyliczenie obejmuje m.in. zadania z zakresu: pomocy społecznej, wspierania rodziny i macierzyństwa, działalności charytatywnej, ochrony i promocji zdrowia, działalności na rzecz osób niepełnosprawnych, nauki i edukacji, kultury i sztuki, sportu i turystyki, ekologii i ochrony przyrody, porządku i bezpieczeństwa publicznego.

Zgodnie z ustawą o d.p.p.w. organy administracji publicznej współdziałają w realizacji określonych przez ustawę zadań publicznych z organizacjami pozarządowymi i innymi podmiotami mogącymi prowadzić działalność pożytku publicznego ${ }^{3}$. Współpraca oparta jest na zasadach pomocniczości (subsydiarności), suwerenności stron, partnerstwa, efektywności, uczciwej konkurencji i jawności (art. 5 ust. 3 u.d.p.p.w.). Prowadzona jest odpowiednio do terytorialnego zasięgu działania organów administracji publicznej oraz ich właściwości rzeczowej. Kooperacja ta odbywa się w różnych formach, których przykładowe wyliczenie zawarte jest w art. 5 ust. 2 pkt 1-7 u.d.p.p.w. Należy do nich m.in.: wzajemne informowanie się o planowanych kierunkach działań, konsultowanie projektów aktów normatywnych, tworzenie zespołów doradczych, czy wreszcie zlecanie organizacjom pozarządowym konkretnych zadań publicznych do realizacji.

Przekazywanie zadań publicznych organizacjom pozarządowym określane jest mianem prywatyzacji wykonywania zadań publicznych. Podkreślić należy, że jednostka samorządu terytorialnego nadal ponosi odpowiedzialność za prawidłową realizację zadań wynikających z przepisów prawa materialnego,

Zakład Ubezpieczeń Społecznych i zarządzane przez niego fundusze oraz Kasa Rolniczego Ubezpieczenia Społecznego i fundusze zarządzane przez Prezesa Kasy Rolniczego Ubezpieczenia Społecznego; Narodowy Fundusz Zdrowia; samodzielne publiczne zakłady opieki zdrowotnej; uczelnie publiczne; Polska Akademia Nauk i tworzone przez nią jednostki organizacyjne; państwowe i samorządowe instytucje kultury oraz inne państwowe lub samorządowe osoby prawne utworzone na podstawie odrębnych ustaw w celu wykonywania zadań publicznych, z wyłączeniem przedsiębiorstw, instytutów badawczych, banków i spółek prawa handlowego.

3 Należą do nich w świetle ustawy osoby prawne i jednostki organizacyjne działające na podstawie przepisów dotyczących stosunku państwa do kościołów i związków wyznaniowych o uregulowanym statusie prawnym, spółdzielnie socjalne, stowarzyszenia jednostek samorządu terytorialnego oraz spółki akcyjne i spółki z ograniczoną odpowiedzialnością działające na podstawie ustawy z dnia 25 czerwca 2010 r. o sporcie (tekst jedn. Dz.U. z 2016 r., poz. 176 ze zm.). 
choć sama już ich bezpośrednio nie wykonuje ${ }^{4}$. Przekazanie zadania organizacji pozarządowej nie oznacza przeniesienia na inny podmiot obowiązku nałożonego na samorząd mocą ustawy ${ }^{5}$. Rozwiązanie to wydaje się w pełni uzasadnione, gdyż cele działalności władz publicznych i organizacji pozarządowych są w wielu punktach zbieżne, a nawet tożsame. Podmioty należące do sektora non-profit działają zaś efektywnie, generując często niższe koszty w porównaniu z jednostkami sektora publicznego ${ }^{6}$. Należy jednak pamiętać, że przekazaniu mogą podlegać tylko takie zadania, przy realizacji których organy administracji publicznej posługują się niewładczymi formami działania. Są to przede wszystkim zadania należące do sfery administracji świadczącej

\section{Dotacje celowe udzielane organizacjom pozarządowym przez jednostki samorządu terytorialnego $w$ świetle ustawy o finansach publicznych}

Określone w przepisach u.f.p. dotacje dla organizacji pozarządowych to dotacje celowe. Stanowi o tym wprost art. 127 ust. 1 pkt 1 lit. e) ustawy. Art. 221 ust. 1 u.f.p. mówi zaś, że podmioty niezaliczane do sektora finansów publicznych i nie działające w celu osiągnięcia zysku mogą otrzymywać z budżetu j.s.t. dotacje celowe na cele publiczne, związane z realizacją zadań tej jednostki, a także na dofinansowanie inwestycji związanych z realizacją tych zadań. W zakresie trybu zlecania zadań i udzielania dotacji u.f.p. odsyła jednak do przepisów ustawy o działalności pożytku publicznego.

$4 \quad$ W literaturze sytuacja taka określana jest mianem odpowiedzialności podzielonej. Jednostka samorządu terytorialnego ponosi odpowiedzialność publicznoprawną za wykonanie nałożonego na nią zadania, natomiast organizacja pozarządowa ponosi odpowiedzialność cywilnoprawną, K. Płonka-Bielenin, Zasady wspótpracy organizacji pozarzadowych z samorzadem gminnym, „Ius et Administratio” 2006, nr 1, s. 64.

5 M. Ofiarska, Zasady zlecania organizacjom pozarzadowym wykonania zadań gminy, „Annales Universitatis Mariae Curie-Skłodowska" 2012, Sectio H, Vol. XLVI, 3, s. 374.

$6 \quad$ J. Małecki, Rola zasobów publicznych w finansowaniu sektora non profit (uzasadnienie, źródła, metody i perspektywy), [w:] A. Pomorska, P. Smoleń, J. Stelmasiak, A. Gorgol (red.), Prawo finansowe w warunkach członkostwa Polski w Unii Europejskiej. Księga Jubileuszowa dedykowana Profesor Wandzie Wójtowicz, Lublin 2011, s. 269.

$7 \quad$ J. Blicharz, Prawna możliwość powierzenia wykonywania zadań publicznych na drodze umownej organizacjom pozarzqdowym, „Acta Universitatis Wratislaviensis” No. 2770, Prawo CCXCV, Wrocław 2005, s. 64. 
Art. 221 ust. 4 u.f.p. nakazuje, aby tryb postępowania o udzielenie dotacji na zadania inne niż określone we wspomnianym już art. 4 ust. 1 u.d.p.p.w. (wymieniającym blisko 40 ich rodzajów) uregulowany został w drodze uchwały organu stanowiącego j.s.t., mając na uwadze zapewnienie jawności postępowania o udzielenie dotacji i jej rozliczenia ${ }^{8}$. Uchwała taka powinna w szczególności określać: sposób informowania organizacji pozarządowych o zadaniach, których realizację j.s.t. zamierza powierzyć podmiotom niezaliczanym do sektora finansów publicznych; zasady wyboru najkorzystniejszej oferty (jest to zwykle procedura konkursowa), formę i termin składania wniosków, czas ich rozpatrywania, sposób powiadamiania wnioskodawców o wynikach postępowania, zasady kontroli realizacji zadania'. Uchwała podjęta na podstawie art. 224 u.f.p. jest aktem prawa miejscowego i podlega nadzorowi regionalnej izby obrachunkowej pod kątem legalności ${ }^{10}$. Po dokonaniu wyboru, zgodnie z zasadami określonymi w uchwale organu stanowiącego j.s.t., $\mathrm{z}$ organizacją pozarządową zawierana jest umowa w przedmiocie udzielenia dotacji celowej na realizację konkretnego zadania. Elementy umowy określa art. 221 ust. 3 u.f.p. Należą do nich: szczegółowy opis zadania i termin jego realizacji; określenie celu, na który dotacja została przyznana; wysokość udzielonej dotacji i tryb jej płatności; termin wykorzystania środków (nie dłuższy niż do 31 grudnia danego roku budżetowego); sposób i tryb kontroli wykonywania zadania; sposób i termin rozliczenia dotacji oraz termin zwrotu niewykorzystanej kwoty.

W przypadku dotacji pobranych nienależnie ( $\mathrm{tj}$. bez podstawy prawnej) lub w nadmiernej wysokości albo wykorzystanych niezgodnie z przeznaczeniem, beneficjent zobowiązany jest do ich zwrotu na rachunek dotującej j.s.t. Jeżeli zwrot taki nie nastąpi we właściwym terminie, organ wydaje decyzję administracyjną określającą kwotę przypadającą do zwrotu oraz termin, od którego naliczane są odsetki jak dla zaległości podatkowych (art. 169 ust. 6 u.f.p.).

8 Przepis art. 221 ust. 4 u.f.p. nie daje organowi stanowiącemu j.s.t. podstawy do określenia w uchwale warunków udzielania dotacji, gdyż te wynikają za art. 221 ust. 1 u.f.p. W drodze uchwały uregulowany może zostać jedynie tryb, czyli procedura udzielania dotacji, zob. uchwała Regionalnej Izby Obrachunkowej w Lodzi z dnia 24 listopada 2010 r., nr 40/179/2010, „Orzecznictwo w Sprawach Samorządowych” 2011, nr 1, s. 99-100.

9 K. Sawicka, [w:] M. Karlikowska, W. Miemiec, Z. Ofiarski, K. Sawicka, Ustawa o finansach publicznych. Komentarz, Wrocław 2010, s. 581-582.

10 Tamże, s. 582-583. 


\section{Dotacje celowe dla organizacji pozarządowych w świetle przepisów ustawy o działalności pożytku publicznego i o wolontariacie}

Ustawa o działalności pożytku publicznego i o wolontariacie w art. 5 ust. 4 przewiduje dwie formy zlecania organizacjom pozarządowym realizacji zadań publicznych. Są nimi odpowiednio powierzenie lub wspieranie wykonywania zadania wraz z udzieleniem dotacji na jego finansowanie.

Powierzenie wykonywania zadania publicznego wiąże się z koniecznością poniesienia większych nakładów finansowych, gdyż dotacja służy w tym przypadku pokryciu wszelkich związanych z nim kosztów. Wspieranie wykonywania zadania oznacza zaś, że dotacja służy jego dofinansowaniu, czyli finansowaniu częściowemu. W tym przypadku oprócz dotacji istnieją inne źródła finansowania zadania, takie jak np. wpływy z ofiarności publicznej, darowizn, umów sponsoringu, środki własne organizacji pozarządowej.

Zlecenie realizacji zadania publicznego przez organizację pozarządową (w formie wsparcia lub powierzenia) możliwe jest tylko w przypadku, gdy dana organizacja prowadzi działalność statutową w dziedzinie objętej przedmiotem zlecenia (art. 11 ust. 1 u.d.p.p.w.). W tej sytuacji podmiot prowadzący działalność w zakresie kultury fizycznej nie będzie mógł otrzymać dotacji przeznaczonej na realizację zadania dotyczącego np. ekologii i ochrony zwierząt ${ }^{11}$.

Wspieranie lub powierzanie realizacji zadań publicznych odbywa się co do zasady w formie otwartego konkursu ofert (art. 10 ust. 2 u.d.p.p.w.). Przyjęcie takiego rozwiązania koresponduje $\mathrm{z}$ wyrażoną $\mathrm{w}$ art. 43 u.f.p. zasadą mówiącą, że prawo realizacji zadań finansowanych ze środków publicznych przysługuje ogółowi podmiotów oraz z treścią przepisu art. 47 u.f.p. zgodnie z którą ten, kto wnioskuje o przyznanie środków publicznych na realizację wyodrębnionego zadania, powinien przedstawić ofertę jego wykonania z poszanowaniem zasad uczciwej konkurencji, gwarantującą jego wykonanie w sposób efektywny, oszczędny i terminowy. Możliwość zaniechania przeprowadzenia konkursu przewidziana została w art. 11a-11c u.d.p.p.w. i dotyczy sytuacji o charakterze nadzwyczajnym, gdy konieczne jest podjęcie szybkich działań,

11 R. Musiałkiewicz, Problemy prawne udzielania dotacji na cele publiczne organizacjom pozarzadowym przez jednostki samorzadu terytorialnego, [w:] A. Borodo (red.), Zagadnienia prawne finansów i gospodarki samorządu terytorialnego, Toruń 2008, s. 264. 
nie skrępowanych koniecznością zachowania procedur konkursowych ${ }^{12}$. Pominięcie trybu konkursowego dopuszczalne jest także, zgodnie z art. 19a u.d.p.p.w. w przypadku zlecania zadań publicznych o charakterze lokalnym lub regionalnym, pod warunkiem łącznego spełnienia dwóch przesłanek: wysokość dotacji nie może przekraczać kwoty 10000 zł oraz zadanie musi być zrealizowane w okresie nie dłuższym niż 90 dni.

Inicjatywa w zakresie zlecenia realizacji zadania publicznego (powierzenia lub wsparcia) może wyjść zarówno ze strony organizacji pozarządowej, jak i organu administracji publicznej. W przypadku, gdy z wnioskiem występuje organizacja pozarządowa, przedstawia w nim opis zadania publicznego przeznaczonego do realizacji oraz szacunkową kalkulację kosztów. Złożone wnioski organ powinien rozpatrzyć w ciągu miesiąca od daty wpływu. Dokonując oceny organ kieruje się kryterium celowości realizacji danego zadania przez organizację pozarządową, koniecznością zapewnienia wysokiej jakości wykonania, dostępnością środków publicznych oraz potencjalnymi korzyściami wynikającymi z realizacji zadania przez organizację pozarządową (art. 12 ust. 2). Organizacja pozarządowa, która wystąpiła z wnioskiem jest informowana o podjętym rozstrzygnięciu. Jeżeli organ administracji publicznej stwierdzi

12 Wymienione przepisy zostały dodane do u.d.p.p.w. na mocy nowelizacji dokonanej ustawą z dnia 22 stycznia 2010 r. o zmianie ustawy o działalności pożytku publicznego i o wolontariacie oraz niektórych innych ustaw (Dz.U. Nr 28, poz. 146). Art. 11a dopuszcza pominięcie procedur konkursowych w sytuacji wystąpienia klęski żywiołowej, katastrofy naturalnej lub awarii technicznej w rozumieniu ustawy z dnia 18 kwietnia 2002 r. o stanie klęski żywiołowej (tekst. jedn. Dz.U. z 2014 r., poz. 333 ze zm.), art. 11b - w sytuacji, gdy jest to niezbędne ze względu na ochronę życia lub zdrowia ludzkiego albo ze względu na ważny interes społeczny lub ważny interes publiczny, art. 11c przewiduje zaś możliwość bezkonkursowego zlecania zadań podmiotom uprawnionym do wykonywania ratownictwa górskiego (zgodnie z ustawą z dnia 18 sierpnia 2011 r. o bezpieczeństwie i ratownictwie w górach i na zorganizowanych terenach narciarskich, Dz.U. Nr 208, poz. 1241 ze zm.), ratownictwa wodnego (zgodnie z ustawą z dnia 18 sierpnia 2011 r. o bezpieczeństwie osób przebywających na obszarach wodnych, tekst jedn. Dz.U. z 2016 r., poz. 656 ze zm.), jednostkom ochrony przeciwpożarowej (zgodnie z ustawą z dnia 24 sierpnia $1991 \mathrm{r}$. o ochronie przeciwpożarowej, tekst jedn. Dz.U. z 2016 r., poz. 191 ze zm.) oraz Polskiemu Czerwonemu Krzyżowi. Zob. też art. 40 ust. 2 ustawy z dnia 16 września 2011 r. o szczególnych rozwiązaniach związanych z usuwaniem skutków powodzi (tekst jedn. Dz.U. z 2015 r., poz. 1401 ze zm.), dotyczący przyspieszenia realizacji wypłaty zasiłku poprzez powierzenie tego zadania organizacji pozarządowej. 
celowość realizacji danego zadania przez NGO, informuje o tym wnioskodawcę oraz wskazuje termin przeprowadzenia otwartego konkursu ofert ${ }^{13}$.

Jeżeli zlecenie realizacji zadania publicznego nastąpić ma z inicjatywy organu administracji publicznej, organ ten ogłasza otwarty konkurs ofert i wyznacza termin do ich składania. W ogłoszeniu o konkursie powinny znaleźć się informacje dotyczące m.in. rodzaju zdania, wysokości środków publicznych zaplanowanych na jego realizację, zasad przyznawania dotacji, terminu i warunków realizacji zadania, terminu składania ofert, trybu i kryteriów stosowanych przy wyborze oferty.

Organizacje przystępujące do konkursu przedstawiają oferty o treści zgodnej z art. 14 ust. 1 u.d.p.p.w. Zawierają one w szczególności: dokładny zakres rzeczowy zadania; termin i miejsce jego realizacji; kalkulację przewidywanych kosztów; informację o wcześniejszej działalności podmiotu w obszarze, którego dotyczy zadanie publiczne; informację o posiadanych zasobach materialnych i kadrowych, zapewniających prawidłową realizację zadania oraz informację na temat innych niż dotacja możliwych źródeł finansowania zadania

Dokonując oceny złożonych ofert, organ administracji publicznej kieruje się kryteriami wyznaczonymi w art. 15 ust. 1 u.d.p.p.w. Ocenie podlegają: możliwość realizacji zadania publicznego przez organizację pozarządową, kalkulacja kosztów w odniesieniu do zakresu rzeczowego zadania, jakość wykonania zadania i kwalifikacje osób zaangażowanych przy jego realizacji. Pod uwagę brany jest wkład rzeczowy i osobowy ze strony organizacji, a także świadczenia wolontariuszy i praca społeczna członków. Jeżeli zlecenie realizacji zadania publicznego ma przybrać formę wsparcia (art. 5 ust. 4 pkt 2 u.d.p.p.w.) pod uwagę brany jest udział własnych środków finansowych organizacji lub środków pozyskanych z innych źródeł.

Wyniki konkursu ofert ogłaszane są niezwłocznie po dokonaniu wyboru oferty w Biuletynie Informacji Publicznej, w siedzibie organu oraz na jego stronie internetowej. Rozstrzygnięcie konkursu nie ma charakteru decyzji administracyjnej, w związku z czym podmiotom, których oferty zostały odrzucone nie służą środki prawne określone w Kodeksie postępowania administracyjnego ${ }^{14}$.

13 Ponieważ postępowanie konkursowe ma charakter otwarty, możliwa jest sytuacja, w której organizacja pozarządowa inna niż pierwotny wnioskodawca złoży ofertę korzystniejszą i tym samym to jej zostanie powierzona realizacja zadania.

14 Ustawa z dnia 14 czerwca 1960 r. (tekst jedn. Dz.U. z 2016 r., poz. 23 ze zm.). 
W ustawie o działalności pożytku publicznego brak jest bowiem przepisu, który stanowiłby materialnoprawną podstawę do wydania takiej decyzji ${ }^{15}$.

Kolejny etap stanowi zawarcie umowy (bądź umów, jako że w świetle art. 15 ust. 2 u.d.p.p.w. wybrana może zostać więcej niż jedna oferta) o wsparcie lub o powierzenie realizacji zadania publicznego z wyłonioną organizacją pozarządową lub innym podmiotem.

Zgodnie z art. 16 ust. 1 ustawy o d.p.p.w. organizacja pozarządowa przyjmując zlecenie realizacji zadania publicznego zobowiązuje się wykonać je w zakresie i na zasadach określonych w umowie, a organ administracji publicznej - do przekazania dotacji na ten cel. Umowa, podobnie jak jej ewentualne zmiany, wymagają zachowania formy pisemnej pod rygorem nieważności. Umowa może zostać zawarta na czas realizacji zadania lub na czas określony, nie dłuższy jednak niż 5 lat. Zawarcie umowy na okres dłuższy niż 1 rok nie oznacza automatycznego zagwarantowania dotacji budżetowej w kolejnych latach, gdyż priorytetem jest zasada roczności budżetu ${ }^{16}$. Wysokość i zakres wydatków determinowane są zaś wielkością zasobów publicznych pozostających $w$ dyspozycji organu $\mathrm{w}$ danym roku budżetowym.

W art. 19 ustawy o d.p.p.w. minister właściwy do spraw zabezpieczenia społecznego upoważniony został do wydania rozporządzenia określającego wzór oferty składanej przez organizacje pozarządowe, ramowy wzór umowy oraz wzór sprawozdania z realizacji zadania publicznego. Wykonując dyspozycję z art. 19 u.d.p.p.w. Minister Rodziny, Pracy i Polityki Społecznej wydał rozporządzenie z dnia 19 sierpnia 2016 r. w sprawie wzorów ofert i ramowych wzorów umów dotyczących realizacji zadań publicznych oraz wzorów sprawozdań z wykonania tych zadań ${ }^{17}$. Użycie w nazwie wzorca umowy określenia „ramowy” wskazuje, że wzorzec ten może być modyfikowany i dostosowywany do potrzeb realizacji konkretnego zadania poprzez umieszczanie w umo-

15 W toku postępowania konkursowego nie są wydawane żadne akty podlegające kontroli sądu administracyjnego. Zob. postanowienie Naczelnego Sądu Administracyjnego z dnia 30 listopada 2011 r., II GSK 2022/11, Centralna Baza Orzeczeń Sądów Administracyjnych (CBOSA, http://orzeczenia.nsa.gov.pl) oraz postanowienie NSA z dnia 11 września 2014 r., I OSK 816/14, CBOSA. Negatywna ocena oferty, skutkująca odmową przyznania środków publicznych na dofinansowanie realizacji zadania nie jest czynnością podlegającą kontroli sądowoadministracyjnej, postanowienie Wojewódzkiego Sądu Administracyjnego w Warszawie z dnia 17 września 2015 r., VIII SA/Wa 475/15, CBOSA.

16 Z. Ofiarski, Finansowanie zadań zleconych przez gminę organizacjom pozarzqdowym, „Annales Universitatis Mariae Curie-Skłodowska” 2012, Sectio H, Vol. XLVI, 3, s. 387.

17 Dz.U., poz. 1300. 
wie postanowień fakultatywnych ${ }^{18}$. Nie mogą one jednak stać w sprzeczności z bezwzględnie wiążącymi elementami wzorca.

Ramowy wzór umowy dotyczącej realizacji zadania publicznego zawiera elementy takie jak m.in.:

- określenie rodzaju umowy;

- datę i miejsce zawarcia;

- oznaczenie stron (zwanych odpowiednio zleceniodawcą i zleceniobiorcą);

- określenie przedmiotu umowy;

- sposób wykonania zadania publicznego;

- zasady finansowania realizacji zadania za pomocą dotacji celowej;

- oświadczenie zleceniobiorcy o środkach finansowych przeznaczonych na realizację zadania, pozyskanych z innych źródeł, zarówno publicznych, jak i prywatnych;

- określenie procentowego udziału dotacji w kosztach całkowitych realizacji zadania;

- zasady prowadzenia dokumentacji;

- zakres obowiązków informacyjnych i sprawozdawczych zleceniobiorcy;

- określenie uprawnień kontrolnych zleceniodawcy;

- zasady i termin zwrotu środków niewykorzystanych;

- przesłanki uzasadniające rozwiązanie umowy za porozumieniem stron, odstąpienie od umowy przez zleceniobiorcę lub rozwiązanie jej przez zleceniodawcę;

- ustanowienie zakazu zbywania rzeczy zakupionych ze środków pochodzących z dotacji;

- zasady odpowiedzialności wobec osób trzecich.

Umowa dotycząca realizacji zadania publicznego ma charakter cywilnoprawny. W sprawach w umowie nieuregulowanych zastosowanie znajdują przepisy Kodeksu cywilnego ${ }^{19}$. Do umowy stosuje się również przepisy ustawy o finansach publicznych, ustawy o rachunkowości ${ }^{20}$, Prawa zamówień publicznych ${ }^{21}$ oraz ustawy o odpowiedzialności za naruszenie dyscypliny finansów publicznych ${ }^{22}$. Oznacza to, że do umowy wprowadzone zostają sui

18 Przykładem postanowienia fakultatywnego jest uzależnienie przekazania kolejnych transz dotacji od wydatkowania określonego procenta przekazanych wcześniej środków.

19 Ustawa z dnia 23 kwietnia 1964 r. (tekst jedn. Dz.U. z 2017 r., poz. 459 ze zm.).

20 Ustawa z dnia 29 września 1994 r. (tekst jedn. Dz.U. z 2016 r., poz. 1047 ze zm.).

21 Ustawa z dnia 29 stycznia 2004 r. (tekst jedn. Dz.U. z 2015 r., poz. 2164 ze zm.).

22 Ustawa z dnia 17 grudnia 2004 r., (tekst jedn. Dz.U. z 2013 r., poz. 168 ze zm.). 
generis elementy publicznoprawne ${ }^{23}$. Spory powstałe w związku z zawarciem i wykonywaniem umowy poddane są, zgodnie z $§ 19$ wzorca, właściwości sądu powszechnego właściwego ze względu na siedzibę zleceniodawcy. Pierwszeństwo przyznano jednak polubownej formie rozstrzygnięcia sporu.

\section{Podsumowanie}

Współpraca jednostek samorządu terytorialnego z organizacjami pozarządowymi w zakresie realizacji zadań publicznych sprzyja podnoszeniu jakości ich wykonywania oraz redukowaniu kosztów. Finansowanie zadań przekazanych do realizacji przez NGO (w formie powierzenia lub wsparcia) dokonywane jest za pomocą dotacji budżetowych. Są to dotacje celowe, wymienione w przepisach u.f.p. Udzielane są na realizację konkretnie oznaczonych zadań, nie zaś w celu pokrycia bieżących kosztów funkcjonowania organizacji.

Jeżeli dane zadanie mieści się w sferze działalności pożytku publicznego, tryb jego zlecenia i finansowania odbywa się zgodnie z przepisami ustawy o działalności pożytku publicznego. Jeżeli zaś dotowane zadanie nie mieści się w katalogu określonym w art. 4 ust. 1 u.d.p.p.w., udzielenie dotacji i zawarcie umowy następuje w trybie przepisów u.f.p. Wymagane jest także podjęcie stosownej uchwały przez organ stanowiący j.s.t.

Dotacje udzielane zazwyczaj są po przeprowadzeniu otwartego konkursu ofert, co ma zapewnić równe traktowanie podmiotów ubiegających się o realizację zadania finansowanego ze środków publicznych. W szczególnych przypadkach przepisy zezwalają jednak na odstąpienie od trybu konkursowego.

Dotacje udzielane są na podstawie umów zawieranych $\mathrm{z}$ beneficjentami. Określają one w szczególności prawa i obowiązki stron, wysokość udzielanej dotacji, tryb i terminy zwrotu środków. Umowy takie zawierane są na podstawie przepisów u.f.p. lub u.d.p.p.w. i przybierają wówczas postać

23 W literaturze funkcjonuje pogląd, iż z uwagi na przeplatanie się w obrębie tej umowy kilku gałęzi prawa (cywilne, administracyjne, finansowe), umowa o wykonanie zadania publicznego posiada szczególny charakter. Przypomina umowę administracyjną, która de lege lata nie jest w polskim porządku prawnym unormowana. Nie jest to także typowa umowa wzajemna w świetle prawa cywilnego, gdyż dotacja nie może być traktowana jako forma wynagrodzenia $\mathrm{z}$ tytułu wykonania zadania. W tej sytuacji, z uwagi na brak odrębnej regulacji prawnej można przyjąć, że jest to umowa cywilnoprawna szczególnego rodzaju, H. Izdebski, Ustawa o działalności pożytku publicznego i o wolontariacie. Komentarz, Warszawa 2003, s. 59-60. 
ustandaryzowanych wzorców (umów ramowych). Umowy te łączą w sobie elementy charakterystyczne dla prawa cywilnego, jak i prawa publicznego (zwłaszcza administracyjnego, finansowego). Obecność elementów publicznoprawnych nadaje tym umowom specyficzny charakter, sytuujący je pomiędzy „klasycznymi” umowami cywilnoprawnymi a nieunormowanymi w polskim prawie umowami administracyjnymi. Z tego względu przyjąć należy, że stanowią szczególną kategorię umów prawa cywilnego.

\section{Literatura}

1. Blicharz J., Prawna możliwość powierzenia wykonywania zadań publicznych na drodze umownej organizacjom pozarzadowym, „Acta Universitatis Wratislaviensis” No. 2770, Prawo CCXCV, Wrocław 2005.

2. Izdebski H., Ustawa o działalności pożytku publicznego i o wolontariacie. Komentarz, Warszawa 2003.

3. Karlikowska M., Miemiec W., Ofiarski Z, Sawicka K, Ustawa o finansach publicznych. Komentarz, Wrocław 2010.

4. Małecki J., Rola zasobów publicznych w finansowaniu sektora non profit (uzasadnienie, źródła, metody i perspektywy), [w:] A. Pomorska, P. Smoleń, J. Stelmasiak, A. Gorgol (red.), Prawo finansowe w warunkach członkostwa Polski w Unii Europejskiej. Księga Jubileuszowa dedykowana Profesor Wandzie Wójtowicz, Lublin 2011.

5. Musiałkiewicz R., Problemy prawne udzielania dotacji na cele publiczne organizacjom pozarządowym przez jednostki samorzadu terytorialnego, [w:] A. Borodo (red.), Zagadnienia prawne finansów i gospodarki samorzqdu terytorialnego, Toruń 2008.

6. Ofiarska M., Zasady zlecania organizacjom pozarządowym wykonania zadań gminy, „Annales Universitatis Mariae Curie-Skłodowska" 2012, Sectio H, Vol. XLVI, 3.

7. Ofiarski Z., Finansowanie zadań zleconych przez gminę organizacjom pozarządowym, „Annales Universitatis Mariae Curie-Skłodowska” 2012, Sectio H, Vol. XLVI, 3.

8. Płonka-Bielenin K., Zasady wspótpracy organizacji pozarządowych z samorządem gminnym, „Ius et Administratio” 2006, nr 1.

Krzysztof Czarnecki

Państwowa Wyższa Szkoła Zawodowa we Włocławku 